\title{
Refugee Determination in Canada
}

\author{
by Raphael Girard
}

On May 21, 1986, after extensive study and consultation, the government announced a package of proposed reforms designed to simplify and improve Canada's refugee determination process.

Highlights of the proposed system include: independent decision-making by a specialized Convention Refugee Determination Division; a non-adversarial oral hearing for claimants on questions of merit; decision-making by twomember panels which offer the benefit of the doubt to the refugee claimant; and the right of an appeal by leave to the Federal Court of Canada on questions of law and jurisdiction. The system also contains reasonable limitations on access, in order to discourage unfounded claims and to prevent long delays for genuine refugee claimants.

In order to deal with new claims arising between May 21 st and the coming into effect of new legislation in 1987, the "fast track" system, consisting of an accelerated inquiry and refugee determination system as it exists in current legislation, but supported with additional resources, was also announced. The "fast track" is not encumbered by the refugee claims backlog as of May 21, 1986. Its objective is to shorten the time for resolution of refugee claims, to put cases through in a few months rather than in several years.

To make fast track work efficiently, certain types of cases have been held out of the system -- nationals of countries to which Canada does not deport, such as Iran, Sri Lanka, Afghanistan, Lebanon, Czechoslovakia, and so on. These cases receive Minister's Permits to provide equivalent protection for up to one year, pending a review of Canada's removals policy.

An administrative clearance of the refugee claims backlog was also announced in the proposed reforms. Over 20,000 claimant cases are eligible for review, concentrated largely in Montreal (45\%), Toronto (45\%) and Vancouver $(5 \%)$. The population is also concentrated in terms of its ethnic and geographic background. Sixty percent of the claimants are from six countries: Guyana, Sri Lanka, Jamaica, Portugal, Iran and El Salvador. Claimants are judged on their establishment or the likelihood of their establishment in Canada. The criteria include: ability; the willingness of relatives to assist; the personal suitability of the applicant; and, the applicant's family obligations. Notwithstanding this assessment, a claimant with close relatives in Canada can be admitted providing the relative is willing and able to sign a guarantee of support.

Guidelines have also been issued pertaining to applicants who cannot meet the test of successful establishment, but who nonetheless merit favourable treatment because of the adverse effects that would result for the claimants, or members of their families, were they returned to their home country.

All successful claimants must meet the requirements of the Immigration Act insofar as medical, criminal, and security screens are concerned. Applicants who are not selected are free to pursue their claims within the existing refugee determination system.

Special offices have been established in Montreal, Toronto and Vancouver to process the backlog of claimants. Elsewhere, the operation is being conducted from regular Canada Immigration Centres by trained staff.
The norm to which the programme works is the provision of a "one-stop" service. In most cases, claimants are informed of the decision upon completion of their interview; if accepted, they become permanent residents of Canada. Pilot interviews with claimants started the last week in August, and the operation will be in full swing by November. To date, some 2,000 cases have been dealt with by the Administrative Review Project. Interviews with claimants will be completed by June or July, 1987.

The legislation to give effect to the announcements made by the Minister of State for Immigration was given prominence in the Speech from the Throne, on October 1st. This is an indication of the government's determination to bring in legislative reform of the refugee determination system, at the earliest possible opportunity.

Raphael Girard is the Co-ordinator of the Refugee Determination Task Force at CEIC.

\section{Annual Report to Parliament on Future Immigration Levels 1986}

The Annual report to Parliament on Future Immigration Levels was tabled on October 30th by Gerry Weiner, Minister of State for Immigration. Canada's intake of 12,000 government-assisted refugees in
1987 repeats the 1986 guidelines. The following statistical table, comparing government-assisted refugee allocations over the past few years, has been compiled using CEIC sources.

\begin{tabular}{|l|c|c|c|c|}
\hline \multicolumn{6}{|c|}{ Government-Assisted Refugee Allocations 1984-1987 } \\
\hline Region & $\mathbf{1 9 8 4}$ & $\mathbf{1 9 8 5}$ & $\mathbf{1 9 8 6}$ & $\mathbf{1 9 8 7}$ \\
\hline S.E. Asia & 3,000 & 3,700 & 3,200 & 3,200 \\
E. Europe & 2,300 & 2,200 & 3,100 & 3,100 \\
Latin America & 2,500 & 3,000 & 3,200 & 3,200 \\
Africa & 1,000 & 1,000 & 1,000 & 1,000 \\
Middle East & 800 & 800 & 900 & 900 \\
Other & 400 & 200 & 300 & 300 \\
Reserve & 2,000 (unfunded) & 100 & 300 & 300 \\
\hline Total & 12,000 & 11,000 & 12,000 & 12,000 \\
\hline
\end{tabular}

